\title{
Alternative concepts for a global financial system - an answer to the present world financial crisis
}

\author{
Conceptos alternativos para una sistema financiero \\ global -una respuesta para la presente crisis financiera
}

\author{
Felix Fuders*
}

\section{Abstract}

Neither interest-capitalism nor communism are natural economic forms, that is, they do not match human nature, but rather are forced by government, meaning that both are destined to fail. Communism leads to laziness and neo-liberalism to greed. In a healthy, that is, natural economic system, neither a planned economy nor interest exist, both of which lead to constrain freedom. With communism, people are enslaved through the forced labour inherent in a planned economy; in an interestbased economy, people are enslaved through the burden of interest, which multiplies exponentially and eventually makes it impossible for an economy to supply households sufficiently, since the exponentially multiplying interest must be earned and paid for.

KEY WORDS: capitalism, communism, interests, freedom.

\section{Resumen}

Ni el capitalismo basado en la obtención de intereses ni el comunismo son formas económicas naturales, esto es, no son propios de la naturaleza

Profesor, Instituto de Economía (FACEA), Universidad Austral de Chile.

Recibido el 28 de enero de 2010; aceptado el 14 de julio de 2010. 
humana sino que son impuestos por el gobierno, lo que significa que ambos están destinados al fracaso. El comunismo conduce al ocio y el neoliberalismo a la codicia. En un sistema económico sano, vale decir natural, no existen una economía planificada ni la obtención de intereses, ambos cuales llevan a limitar la libertad. El comunismo esclaviza debido al trabajo obligatorio que impone una economía planificada; el capitalismo basado en la obtención de intereses esclaviza a través de la carga de los intereses que se multiplican de manera exponencial y con el tiempo impiden que la economía pueda proveer suficiente apoyo a las familias, debido a que estos intereses deben ser ganados y pagados.

Palabras claves: capitalism, comunismo, intereses, libertad. 
Felix Fuders • A global financial system without interest...

FORCED GROWTH - THE LOGIC

\section{BEHIND INTEREST}

An economy based on interest destroys itself at set intervals. This is not difficult to understand, since financial assets double themselves in accordance with interest rates through interest and compound-interest in approximately 10 - 15 years. Even the fastest calculator in the world some day will no longer be able to keep up with the resulting interest burden for lack of zeroes ${ }^{1}$. This is the logic of an exponential-function ${ }^{2}$. Still less can an economic system ever achieve a great enough economic performance to satisfy the demand for interest. Here we find the cause of the rapidly and ever more rapidly growing money supply which then led necessarily to the stock- and real estate-bubbles, and to the resulting financial crisis. The US Federal Reserve has not been making the money supply $\mathrm{M} 3$ public since 2006, and for a good reason ${ }^{3}$. People

1 To illustrate the problem the so-called Joseph's penny is suitable. If Jesus had inherited merely a penny from Joseph, and if this penny had been deposited in a bank with a $5 \%$ interest rate, the investment in 1990 would have amounted to 123 billion globes of pure fine gold, see Günter Hannich, Börsencrash und Welt-Wirtschaftskrise - Der Weg in den Dritten Weltkrieg, 4th ed., 2005, p. 15.

2 That money growth due to the compounding effect follows an exponential function also turns out in Margit Kennedy, Geld ohne Zinsen und Inflation - Ein Tauschmittel, das jedem dient, 1990, p. 22 f.

3 See www.federalreserve.gov/Releases/h6/ discm3.htm. otherwise might notice that the money supply is growing considerably more quickly than the productivity of the world economy ${ }^{4}$. This is also the reason why all industrialised nations, as well as those wishing to become so, are striving for economic growth ${ }^{5}$. Production must increase every year in order to pay for the interest. The increase in production is measured in relation to the previous year's level.

$4 \quad$ The dollar money supply M3 is developing exponentially, see: en.wikipedia.org/wiki/ Money_supply; http://www.economagic. com/em-cgi/cha...xe/fedstl/m3sl. For the moderate evolution of the growth of world productivity see: International Monetary Fund, World Economic Outlook - Financial Systems and Economic Cycles, Washington 2006, p. 1 . The productivity of the economy actually shrank at last, see. OECD, Economic Outlook, Paris, Vol. $2008 / 2$, No. 84 , p. 6,12 , 15 . It was highlighted that the growth of the quantity of goods in the world in the last 30 years, increased only four times, while the monetary side has increased forty-fold, cf. Eberhard Hamer, Der Welt-Geldbetrug, in: Zeit-Fragen 2004, No. 45, p. 1; id./Eike Hamer, Was passiert, wenn der Crash kommt?, 6th ed., 2005, p. 32.

5 Margit Kennedy, Geld ohne Zinsen und Inflation, p. 159; Karl Albrecht Schachtschneider, Verfassungsrecht der Europäischen Union, to appear in print., $\mathbb{S} 14$, I. 3 e); Wilhelm Hankel, Währungspolitik, Geldwertstabilisierung, Währungsintegration und Sparerschutz, 2d ed. 1972, p. 71ff., 103ff.; Helmut Creutz, Das Geldsyndrom. Wege zu einer krisenfreien Marktwirtschaft, 1993; Günter Hannich, Sprengstoff Geld: wie das Kapitalsystem unsere Welt zerstört, 2d. ed. 1999, p. 45 ff.; Werner Lachmann, Volkswirtschaftslehre 1, 4th ed. 2003, p. 184 ff. 
The problem is that demand and production cannot be increased arbitrarily - there simply aren't enough resources. It is also not understandable why more should continually be produced although a high level of prosperity has already been achieved. Extravagance, predetermined breaking points in products, disposable products, «scrapping incentives» and - again very up-to-date - even the invention of diseases ${ }^{6}$, are symptomatic of the problem in the system. The economy tries compulsively to maintain economic growth. When percentile economic growth falls behind the rate of interest, the State must finally make up the difference by going into debt. This is a reason for the high and ever more rapidly increasing level of national debt among industrialised nations. Or in

6 Cf. Lynne McTaggart, What Doctors Don't Tell You: The Truth About the Dangers of Modern Medicine, 2005; Vernon Coleman, How to Stop your doctor killing you, 2003; Jörg Blech, Die Krankheitserfinder - Wie wir zu Patienten gemacht werden, 2005; Torsten Engelbrecht/Claus Köhnlein, Virus-Wahn: Vogelgrippe (H5N1), SARS, BSE, Hepatitis C, AIDS - Wie die Medizin-Industrie ständig Seuchen erfindet und auf Kosten der Allgemeinheit Milliarden-Profite macht, 3rd ed. 2006; Michael Leitner, Mythos HIV - Eine Kritische Analyse der AIDS-Hysterie, 2000; Stefan Lanka/Hans-Ulrich Niemitz/ Veronika Widmer/Karl Krafeld, Die Vogelgrippe - Der Krieg der USA gegen die Menschheit, 2006; Veronika Widmer/ Stefan Lanka/Susanne Brix, Der MasernBetrug, 2006; Kurt Blüchel, Heilen verboten - töten erlaubt. Die organisierte Kriminalität im Gesundheitswesen, 2003. other words: interest on one side necessarily leads to debt on the other, since there is no interest without debt. The interest- induced self-increasing money supply therefore automatically leads to higher total indebtedness ${ }^{7}$.

\section{HigH CREDIT RISKS, CASINO MENTALITY, INFLATION: \\ SECONDARY PHENOMENA OF THE}

\section{INTEREST ECONOMY}

The continually, ever accelerating increase of money in circulation can, at some point, no longer be covered by productivity, which cannot grow continually, since there is no endless growth in nature. This leads necessarily to inflation, although only partially at first, i.e. in investment markets. Price bubbles in stock and real estate markets corroborate this impressively ${ }^{8}$. This self-multiplying money seeks forms of investment. Responsibility for financial bubbles thus lies neither with irresponsible bank traders who do not properly

\footnotetext{
Cf. Günter Hannich, Börsencrash und Welt-Wirtschaftskrise, p. $21 \mathrm{f}$. Also already Aristoteles, who recognized that the macroeconomic interest revenue accurately reflects the interest cost of debt, see: Ulrich van Suntum, Die unsichtbare Hand - Ökonomisches Denken gestern und heute, 3rd ed. 2005, p. $73 \mathrm{f}$.

8 The price bubbles have been denominated a „partial « inflation; cf. Karl Albrecht Schachtschneider, Armes Europa - armes Deutschland: Wird Europa eine Oligarchie der Unternehmens- und Parteiführer? Gedanken zur Grundrechtsproblematik der EU, in: Zeit-Fragen, 1999, No. 62, p. 1.
} 
Felix Fuders • A global financial system without interest...

evaluate credit risks nor with the often criticised casino-like games played by banks in the markets; it results rather from pressures to invest capital for a high return. The all too easily acquired loans, casino-like gambling and the lack of bank supervision, however, are suggested in the media and literature as the cause of the financial crisis ${ }^{9}$. Very likely it is desired to keep the majority ignorant regarding the causes of the coming financial crash in order to make a facilitate subsequent post-crash re-establishment of an interest-based system.

\section{HYPERINFLATION:}

POSSIBLE AGAIN

One can therefore expect little public resistance, as egregious errors in the system would, most people might think, naturally be excluded this time ${ }^{10}$. In the same way, most people are virtually convinced that hyperinflation like that of 1923 in Germany would now be impossible, because the State would not make the mistake of print-

9 Cf. Paul Krugman, The return of depression economics and the crisis of 2008, 2008; Robert J. Shiller, The subprime solution: How today's global financial crisis happened, and what to do about it, 2008; Ulrich Schäfer, Der Crash des Kapitalismus, 2008; Holger Steltzner, Auf dem Londoner Gipfel, F.A.Z.v. 02.04.2009, p. 1.

10 References mentioned in the previous footnote contain suggestions for how we might avoid the mistakes in the future. The real cause, interest rate, is not discussed. ing money. This is what history books teach us. In reality, however, in 1923 the German State was compelled to print money not only because of reparations from the Treaty of Versailles, but also because the interest-burden of national and war debts climbed endlessly. The US Federal Reserve as well as the ECB find themselves in a similar dilemma today and have already begun printing money ${ }^{11}$. However nowadays this is more elegantly called «buying back of national bonds» ${ }^{12}$.

\section{MONEY DOESN'T WORK, BUT PEOPLE DO}

Beside the fact that an interest-based financial system is self-destructive ${ }^{13}$, it is also the reason that the gap between rich and poor, and in the end also the gap between rich and poor countries ${ }^{14}$, continues to expand, as has been proven ${ }^{15}$. People within interest capitalism can be therefore divided into two groups: those who work and so are genuinely productive, and those

11 Similar interpretation offers Holger Steltzner, Auf dem Londoner Gipfel, F.A.Z. v. 02.04.2009, p. 1.

12 Cf. www.n-tv.de/1093635.html; cf. also Markus Frühauf, Die Verstaatlichung des Anleihemarktes, F.A.Z. v. 02.04.2009, p.9.

13 Also Karl Marx, Das Kapital. Kritik der politischen Ökonomie, Bd. III, 3rd ed. 1911, p. $191 \mathrm{ff}$.

14 Cf. Margit Kennedy, Geld ohne Zinsen und Inflation, p. 85 ff.

15 Günter Hannich, Börsencrash und WeltWirtschaftskrise, p. 59 f.; Margit Kennedy, Geld ohne Zinsen und Inflation, p. $28 \mathrm{ff}$. 
who live off of that work and whose power continually grows ${ }^{16}$. Thus, the recipient of social welfare is no more taking advantage of others than the one living off interest. That is because money does not actually work, as banks propaganda would often have us believe. It is rather the people who must yield the interest amounts. The success of the competitive economy ought only to be contingent upon the capabilities of human beings. Neither money nor guaranteed privileges, but rather efficiency, power, love and wisdom should be praised by people for their successes, as German-Argentine economist Silvio Gesell pointed out ${ }^{17}$.

\section{INTEREST-DRIVEN MONEY}

\section{HOARDING AND FLUCTUATION}

\section{IN BUSINESS ACTIVITY}

Regardless of the fact that interestbased economic systems eventually create so much book money that the resulting money-bubble some day must burst, in other words, that economic performance can never cover the exponentially increasing money supply resulting from interest, the smaller business fluctuations might also result

16 According to Silvio Gesell society divides into beasts of burden and retirees, cf. Silvio Gesell, Die natürliche Wirtschaftsordnung, 9th ed. Lauf 1949, p. 27. Translation into English by Philip Pye, The Natural Economic Order, London 1958.

17 Similarily Silvio Gesell, Die natürliche Wirtschaftsordnung, 4th ed. Bern 1938, p. VIII. from interest. Money was invented to facilitate the exchange of goods and therefore must flow. On the other hand, the hoarding of money, which leads to a recession of economic performance, can only be prevented by offering the money holder an incentive to lend it, which we call interest. But high interest rates also lead to recession. In turn, fear of a crisis encourages hoarding, which makes even higher interest rates necessary. A self-feeding process arises which is probably a considerable cause of business fluctuations. This means that even within the time-frame in which the system has not yet collapsed, business fluctuations are strongly linked to interest in connection to people's psychological situation ${ }^{18}$.

\section{UNNECESSARY PRODUCTION AND WARS FOR THE SAKE OF PAYING INTEREST}

Interest is probably also a powerful factor behind environmental pollution and overstraining. In addition to forced economic growth, which necessarily accompanies an overstraining of the environment ${ }^{19}$, there is another environmentally damaging effect. Normally, there would only be as much produced as is actually consumed. The perishability and technical obsolescence of

18 Silvio Gesell, Die natürliche Wirtschaftsordnung, 9th ed. 1949, p. $199 \mathrm{ff}$.

19 Margit Kennedy, Geld ohne Zinsen und Inflation, p. 160; Günter Hannich, Börsencrash und Welt-Wirtschaftskrise, p. 61. 
Felix Fuders • A global financial system without interest...

products naturally keep surpluses in check. As long as it is higher than inflation, interest makes job performance retainable. If one were to put money into an account with no interest, it would slowly lose value due to inflation, just as products lose value through deterioration or technical obsolescence. But interest that makes up for inflation permits hoarding of the value produced. Furthermore, it has been comprehensibly demonstrated that many wars are apparently connected with the interest economy ${ }^{20}$. The interest burden of the State is to be paid for with captured capital and resources. The most recent wars in Iraq and Afghanistan appear to support this view. On the other hand, war is the most effective method to destroy values, which in turn allows new economic growth and thus, paying interest. Also, since war is expensive, it leads to governments of nations at war increasing their national debt.

\section{Silvio Gesell, Irving Fisher and John Maynard Keynes}

Most of this was already recognised by Silvio Gesell 100 years ago, who proposed the so called free money; that is, money free of interest ${ }^{21}$. Tax stamps which are to be fixed on bank notes at specified intervals are to provide an incentive not to hoard money.

20 Günter Hannich, Börsencrash und WeltWirtschaftskrise, p. $207 \mathrm{ff}$.

21 Cf. Silvio Gesell, Die natürliche Wirtschaftsordnung, p. $235 \mathrm{ff}$.
Money thus loses its unnatural position in relation to specific products, as it is now perishable, just as goods are. The owner of the funds can now no longer demand interest for lending his money ${ }^{22}$, exploit the scarcity-value of capital as formulated by John Maynard Keynes ${ }^{23}$. Such money is natural money because it devalues just as real goods do. Therefore pressure on money supply will increase, which should lead to interest rates approaching zero ${ }^{24}$. Creditors even lend money freely, since borrowers promise to repay the full amount and creditors are exempted from paying the tax $s t a m p^{25}$. That means: by liberating money from its inexorable character ${ }^{26}$ from its unnatural and special position in relation to goods, the likewise unnatural interest rate should also disappear ${ }^{27}$. Famous economists John Maynard Keynes and Irving Fisher considered this idea as a possible solution for the Great Depres-

22 Silvio Gesell, Die natürliche Wirtschaftsordnung, p. 205, 344.

23 John Maynard Keynes, Allgemeine Theorie der Beschäftigung, des Zinses und des Geldes, p. 317.

24 Silvio Gesell, Die natürliche Wirtschaftsordnung, p. 239, 242, 252 f., 264 f., 270, 273, 284, 329, 342, $344 \mathrm{f}$.

25 Silvio Gesell, Die natürliche Wirtschaftsordnung, p. $264 \mathrm{f}$.

26 Silvio Gesell, Die natürliche Wirtschaftsordnung, p. 238.

27 That interest is contrary to the laws of nature, also turns out Wolfgang Berger, Die Finanzmarktkrise, in: Hintergrund 1/2009, p. 9; also already in Aristotle, Politics, 1st Book, 1258b. 
sion of the $1930 \mathrm{~s}^{28}$. The former was convinced that «the future will learn more from the spirit of Gesell than from that of Marx» ${ }^{29}$. Later, at the Bretton Woods conference, Keynes proposed an international currency of that type called Bancor. Irving Fisher considered himself only a modest apostle of Silvio Gesell $^{30}$ and even wrote a book on the concept of free money ${ }^{31}$.

28 John Maynard Keynes, Allgemeine Theorie der Beschäftigung, des Zinses und des Geldes, p. 298 ff.; Irving Fisher, Booms and Depressions, 1933, p. 226 ff.; Irving Fisher, Stamp Scrip, 1933, Kap. I.

29 John Maynard Keynes, Allgemeine Theorie der Beschäftigung, des Zinses und des Geldes, p. 300. Gesell's remarks, however, Keynes thought to be incorrect, because Gesell had not recognized household's preference for liquidity (p. 301). This is not true. Rather it is just the liquidity preference which generates the special position of money in comparison to goods, the starting point for Gesell's deliberations. To abandon these special circumstances and to make the hoarding of money as unattractive as the hoarding of goods, is the sense of Gesell's stamped money. Conversely, it seems that Keynes did not recognize the reason for the existence of household's preference for liquidity: the monopoly of money over goods (cf. p. 163 ff.).

30 Irving Fisher, Feste Währung - Illusion und Wirklichkeit, 1947, Preface of publisher, p. 6.

31 Irving Fisher, Stamp Scrip, 1933. It should be noted that Irving Fisher took over the idea of a Free Money from Silvio Gesell, as he had seen hoarding as a problem of deflation. Interest rate and the fact that interest rate as non-hoarding prime generates from the possibility to hoard money, is not explicitly discussed (and even explicitly rejected in: Irving Fisher, Feste Währung, p. 117 Fn. 56). Rather, in his

\section{Alternatives to Silvio GESELL'S FREE MONEY}

The question is however, if the cumbersome free money system, or proposed electronic banknotes which devalue over time ${ }^{32}$, are necessary at all. Were there no interest, money stored in accounts would automatically devalue through inflation ${ }^{33}$. Even if one questioned whether there would be inflation in case interest ${ }^{34}$ did not exist,

opinion the main cause of deflation is debt, without recognizing interest rate as a major cause of indebtedness (cf. Irving Fisher, The Debt Deflation Theory of Great Depressions, in: Econometrica Vol. 1 No. 4 (1933), insb. p. 344; id., Booms ans Depressions, p. 8 ff. ).

32 Wolfgang Berger, Die Finanzmarktkrise - Ergebnis einer Fehlkonstruktion, die wir korrigieren können, in: Hintergrund 1/2009, p. 13-16.

33 Natural inflation arises from the fact that production is approaching a saturation state in which just as many new products are produced as old ones become obsolete, due to abrasion or technical aging. Every new product, however, leads to a real economic profit, which increases money supply. Natural inflation is an incentive to invest money and not hoard, as in the exchange economy goods may also not be kept forever. Natural inflation is much lower than the present one and does not bring along exponential increase of money supply. Whether or not there exists such a natural inflation, however, is not proven. The relationship between interest rate and inflation is discussed controversially; cf. Friedrich A. Lutz, Zins und Inflation, in: Walter Eucken Institut, Vorträge und Aufsätze, No. 42, Tübingen 1973, p. 10.

34 Margit Kennedy, Geld ohne Zinsen und Inflation, p. $31 \mathrm{ff}$. 
Felix Fuders • A global financial system without interest...

banks would need to require a deposit fee, because if they cannot earn money through interest, fees would need to be their source of income. Money deposited in a bank would therefore lose value in a system without interest, even assuming that in such a system there would be no inflation. Since it is unsafe to hoard greater amounts of money at home, people would be compelled to either freely lend their money or place it in productive investments. If interests were forbidden, lending money illegally on the black market would neither be an option. The debtor would have no obligation to fulfil his promise to pay interest, since the lender would not be able to take legal action. As is the case in Silvio Gesell's solution, hoarding money in bank accounts would be just as unprofitable as hoarding capital assets. In order to ensure the circulation of money, it would also be worth considering government regulation of bank fees, similar to the way central banks set the prime rate today. Progressions would also be a possibility, so that the fee rises in accordance with how much more money, or how much longer the money is out of circulation. In order to protect small investors' money from devaluation, accounts might be exempted of deposit fees up to a certain amount.

While Silvio Gesell's free money would impose carrying costs, as John Maynard Keynes called the tax stamps ${ }^{35}$,

35 John Maynard Keynes, Allgemeine Theorie der Beschäftigung, des Zinses und des Geldes, p. 300 f. which in theory would induce interest rates to tend towards zero, a ban on interest the other way round should lead to carrying costs in the form of deposit fees. Apart from Silvio Gesells such custodian fees provide free money, an incentive to lend money voluntarily and free of charge, to avoid drop of purchasing power.

\section{Negative Central Bank \\ INTEREST RATES MIGHT BE THE BEST ALTERNATIVE}

Negative interest rates were being considered by Willem Buiter of the London School of Economics ${ }^{36}$ and also recently by Harvard Professor Gregory Mankiw $^{37}$. For the first time ever in the history of Central Banks, the Swed-

36 Willem H. Buiter, Overcoming the Zero Bound: Gesell vs. Eisler - Discussion of Mitsuhiro Fukao.s «The Effects of Gesell (Currency) Taxes in Promoting Japan.s Economic Recovery», in: International Economics and Economic Policy, Vol. 2, No. 2-3, 2005, p. 189-200; id./Nikolaos Panigirtzoglou, Overcoming the Zero Bound on Nominal Interest Rates with Negative Interest on Currency - Gesell's Solution, in: Economic Journal, Vol. 113, No. 490, 2003, p. 723-746; id., Negative Interest Rates: Three ways to overcome the zero lower bound, Paper presented at the Center for Financial Studies, Goethe University, Frankfurt on 6th May 2009; id./Nikolaos Panigirtzoglou, Liquidity Traps - Gesell's Solution, in: Bank of England (ed.), Working Paper v. 31.05.1999.

37 Gregory Mankiw, It may be time for the Fed to go negative, in: New York Times v. 19.04.2009. 
ish Central Bank introduced negative prime rates in June $2009^{38}$. Negative interest rates might be also an alternative to Silvio Gesell's free money. They would mean that commercial banks had to pay a fee for their deposits with the Central Bank, instead of receiving interest. Loans from the Central Bank to commercial banks would be free of charge. If prime rates are negative enough, loans from commercial banks to their clients would also be free, or nearly free, of interest (banks might, however, charge a commission). This means that in the same way as in Silvio Gesell's free money system, the pressure on money supply could lead to interest rates falling to near zero. On the other hand, banks would not be able to pay interest on saving deposits, while a deposit fee would probably not be possible either because otherwise no one would deposit money at a bank, but banks would still want to broker credits. Should the demand for credit be low a deposit fee alone might be conceivable. Then, many would probably prefer to hoard smaller amounts of money at home, which should have no adverse effect on the economy since this would only happen if demand for credit is respectively low. Here we find the difference to Silvio Gesell's solution, where money hoarded at home pays the hoarding tax. A bank would become what it used to be and what it was

38 See website of Swedish Central Bank: http://www.riksbank.com/templates/Page. aspx?id=32559. originally named after: an institution in which people deposit their money because it is safer there than at home. At the same time, it would be an agent for obtaining free loans who would charge a commissioner's fee. If credit is free of interest, the economy's money supply cannot further be separated from the development of the economy's productivity. Thus, the danger of a collapse of the financial system would be reduced significantly.

\section{RETURN ON PRODUCTIVE}

\section{INVESTMENT INSTEAD}

\section{OF UNNATURAL SELF-}

\section{MULTIPLICATION OF FIAT MONEY}

The fact that economic science labels all types of earnings as interest ${ }^{39}$, must not lead to a confusion of returns driven out of productive investments with loan interest. The latter generates interest independently from the development of economic production, and thus originates an unnatural selfaggrandisement of money supply ${ }^{40}$.

39 Even Silvio Gesell himself called production gains as interests, vgl. Silvio Gesell, Die natürliche Wirtschaftsordnung, z. B. p. 204.

40 In the Koran, Muhammad condemned this equalization of productive gains with lending rates. He was sure that those who would do such an equalization will be punished, 2.275. Also the Bible prohibits interests; cf. Exodus 22,24; Leviticus 25,36-37; Deuteronomy 23,20 and 24,10; Ezekiel 18,13 und 22,12; Luke 6,35; Psalm 15,5; Probverbs 28,8. Already Aristotle found money reproducing money 
Felix Fuders • A global financial system without interest...

But in an interest-free system there is also the possibility of obtaining profit, investing money productively. That is, in an interest-free economy, capital can also be invested profitably, and so yield a return. This return, however, is based on real economic output, that is to say, value has been produced. The same applies, for example, to the case of companies selling products with date of payment and asking a higher price to cover the payment risk, a business conduct which of course would be equally possible in an economic system without interest. Economists understand dates of payment as a form of credit whereby the mark-up represents the interest in this view $^{41}$ - an interpretation which leads to the above mentioned confusion. However, a mark-up is a return with a productive background and not a form of interest. The higher price reflects the costs of lending the product and not the money, until payment. In this case, it is money not earned with money.

Accordingly, in an interest-free economy, where only productive earnings exist, there are no spin-offs of the financial markets in relation to the productive economy ${ }^{42}$ and therefore

to be an unnatural phenomenon; cf. Aristotle, Politics, 1st Book, 1258b.

41 Cf. Manfred Borchert, Geld und Kredit: Einführung in die Geldtheorie und Geldpolitik, 8th ed.2003, S.33; Jochen Drukarczyk, Finanzierung, 9th ed. 2003, S. 480; Jürgen Stiefl, Finanzmanagement, 2005, S. 60

42 Eberhard Hamer/Eike Hamer, Was passiert, wenn der Crash kommt?, 6th ed. 2005, p. 19, 32. no money bubbles. However, in an economic system with a continually increasing money-supply, people are, as already shown, forced to cover this money through production. Worldwide production has already fallen far behind the exponentially growing money-supply ${ }^{43}$. Even companies not financed through foreign capital are not free from being forced to achieve a return as high as interest on borrowed capital. Otherwise, opportunity costs make maintaining production appear pointless. This is probably why some groups earn huge parts of their annual profits through financial investments rather than the production of goods.

\section{INVESTMENT INCENTIVE}

\section{THROUGH PARTICIPATION IN}

\section{REAL ECONOMIC PROFITS}

It is worth asking how companies in an economic system in which loan interest does not exist (whether this is through implementation of Silvio Gesell's solution or the prohibition of interest rates or negative Central Bank interest rates) can be sufficiently supplied with investment capital. A bank

43 Eberhard Hamer, Der Welt-Geldbetrug, Zeit-Fragen 2004 No. 45, S 1; id./Eike Hamer, Was passiert, wenn der Crash kommt?, 6th ed. 2005, p. 32; International Monetary Fund, World Economic Outlook - Financial Systems and Economic Cycles, Washington 2006, p. 1. World productivity shrank at last, cf. OECD, Economic Outlook, Paris, Vol. 2008/2, No. 84, p. 6, 12, 15. 
will probably not want to participate in corporate risks in exchange of a more commissioner's fee. If there is no interest covering up risks, there is less incentive to make capital available for risky productive investments. But, as mentioned earlier, nothing prevents making a profitable investment, i.e. an investment in corporate equity capital. Just as loan agreements have a set running time today, so can participation in equity capital be established for a set period of time in order to give the entrepreneur planning reliability. What is paid back is not the amount paid in, but rather the amount matching the proportion of net equity. The investor is thus naturally participating in the company's risk, just as with any other participation in equity capital. Possible positive return matches the corporation's real economic profit. When equity capital participation is the sole form of gaining a positive return on investment, money in circulation cannot become decoupled from the productivity of the political economy.

\section{FUNDS FOR SMALL INVESTORS}

To also give small investors the possibility of participating in the equity capital of corporations on one hand, and to give small and medium-sized companies the chance to find financiers on the other, guilds, (chambers of industry, trade, crafts, etc.) for example, could act as mediators and drive funds in which small investors invest their money for a set period of time. The fund invests the moneys for an equally fixed period of time in the equity capital of the connected companies. Such funds would also have a risk-reduction function for the small investor. Incidentally, with the loss of the interest burden, companies would either generate higher profits or lower their prices, bringing profit to either the investor or the consumer. Interest revenues now pocketed by banks would thus accrue to households ${ }^{44}$.

\section{SUMMARY}

In summary, it can be said with certainty that an economy built on interest has no choice but to collapse. Furthermore, interest is at fault for the overstraining of our environment, the raping of resources and for the widening gap between rich and poor. An economic system should be a genuinely free market economy, namely free of interest. Negative Central Banks' interest rates seem to come close to the idea of free money proposed by Silvio Gesell, provided they are negative enough to ensure that interest rates of loans to clients from commercial banks tend towards zero. In contrast to free money, the latter has a far greater chance of becoming implemented due to a lower level of resistance on the part of stake holders.

44 This is no small sum. It was shown that prices compound $30-50 \%$ of interest, cf. Margit Kennedy, Geld ohne Zinsen und Inflation, p. $25 \mathrm{ff}$. 